\title{
STRUKTUR DAN DISTRIBUSI PENDAPATAN RUMAH TANGGA PETANI PADI SAWAH DI DESA CAYUR KECAMATAN CIKATOMAS KABUPATEN TASIKMALAYA
}

\author{
STRUCTURE AND DISTRIBUTION OF FIELDS PADDY FARMERS HOUSEHOLD \\ INCOME IN CAYUR VILLAGE CIKATOMAS DISTRICT TASIKMALAYA REGENCY
}

\author{
ADE DINI ${ }^{*}$, TRISNA INSAN NOOR ${ }^{2}$, MUHAMAD NURDIN YUSUF ${ }^{1}$ \\ ${ }^{1}$ Fakultas Pertanian Universitas Galuh Ciamis \\ ${ }^{2}$ Dosen Fakultas Pertanian Universitas Padjadjaran \\ E-mail : diniadin28@gmail.com
}

\begin{abstract}
ABSTRAK
Secara umum sumber utama pendapatan rumah tangga petani padi sawah di Desa Cayur berasal dari sektor pertanian, namun kepemilikan lahan petani mayoritas sempit $(<0,5 \mathrm{ha})$ dan fakta menunjukkan bahwa produksi usahatani padi sawah memiliki risiko tinggi menyebabkan petani tidak hanya mengandalkan dari satu sumber pendapatan untuk memenuhi kebutuhan rumah tangga sekaligus menciptakan kesejahteraan keluarganya. Penelitian ini bertujuan untuk menganalisis: 1) Struktur pendapatan, 2) Distribusi pendapatan, dan 3) Tingkat kesejahteraan rumah tangga petani padi sawah. Metode yang digunakan adalah survey, teknik penarikan sampel responden menggunakan simple random sampling dengan slovin pada tingkat kesalahan 15 persen dan diperoleh 37 responden petani padi. Struktur pendapatan dihitung menggunakan analisis persentase sedangkan untuk analisis distribusi pendapatan dihitung dengan Gini Indeks serta tingkat kesejahteraan dengan BPS dalam Susenas 2016. Hasil penelitian menunjukkan bahwa: 1) Pendapatan petani dari usahatani adalah Rp 5.536.114,7,- pendapantan dari non-usahatani adalah Rp 9.742.702,7,- dan non-pertanian adalah Rp 13.039.459,46,-. Struktur pendapatan dari sektor pertanian berkontribusi paling besar yaitu 54\%, sedangakn sektor non-pertanian berkontribusi sebesar 46\%. 2) Distribusi pendapatan menunjukkan ketimpangan rendah dengan indek gini sebesar 0,09 menunjukkan tidak terjadi ketimpangan pendapatan. 3) Tingkat kesejahteraan rumah tangga petani padi sawah di Desa Cayur seluruhnya dikategorikan tidak miskin. Berdasarkan 11 indikator ekonomi dan sosial (BPS-SUSENAS 2016) sekor rata-rata yang di peroleh adalah 27,9 yang menunjukkan tingkat kesejahteraan seluruh rumah tangga petani termasuk tingkat sejahtera tinggi.
\end{abstract}

Kata Kunci: Struktur pendapatan, distribusi, indeks gini rasio, kesejahteraan, petani padi, rumah tangga petani.

\begin{abstract}
In general, the main source of household income for lowland rice farmers in Cayur Village comes from the agricultural sector, but the of farmers' land ownership majority is narrow $(<0.5 \mathrm{ha})$ and the fact shows that low-risk rice farming production has made farmers not only rely on one source of income to meet household food security while creating family welfare. This study aims to analyze: 1) income structure, 2) income distribution, and 3) the level of household welfare of paddy farmers. The method used was a survey, the sampling technique used was simple random sampling with Slovin at an error rate of 15 percent and obtained 37 respondents of lowland paddy farmers. The income structure is calculated using percentage analysis, while for the analysis of income distribution it is calculated using the Gini Index and the level of welfare with the BPS in Susenas 2016. The results showed that: 1) Farmers' income from farming was $R p$ 5,536,114,7,- income from non-farming is $R p$ 9,742,702.7,- and non-agriculture is $R p$ 13,039,459.46,-. The income structure from the agricultural sector contributed the most at $54 \%$, while the non-agricultural sector contributed $46 \%$. 2) The income distribution shows low inequality with a Gini index of 0.09 indicating that there is no income inequality. 3) The level of household welfare of lowland rice farmers in Cayur Village is all
\end{abstract}


categorized as not poor. Based on 11 economic and social indicators (BPS-SUSENAS 2016), the average score obtained is 27,9 which shows the level of welfare of all farmer households including the high level of welfare.

Keywords: Revenue structure, distribution, gini ratio index, welfare, paddy farmers, farmer household.

\section{PENDAHULUAN}

Sektor pertanian adalah salah satu sektor yang sangat penting dalam menunjang perekonomian Indonesia. Sampai saat ini, prioritas pembangunan di Indonesia diletakkan pada pembangunan bidang ekonomi dengan titik berat pada sektor pertanian. Salah satu subsektor yang termasuk kedalam sektor pertanian adalah subsektor tanaman pangan (Martina, 2018).

Padi merupakan komoditi penghasil beras yang menjadi tanaman pangan utama bagi penduduk Indonesia. Produksi padi juga perlu ditingkatkan secara keberlanjutan karena beras merupakan bahan pangan pokok bagi masyarakat Indonesia, serta merupakan komoditas penting umtuk menjaga ketahanan pangan. Usahatani padi juga menciptakan lapangan kerja yang besar dan berkontribusi terhadap pendapatan rumah tangga cukup besar (Hamdan, 2013).

Rumah tangga petani merupakan unit ekonomi yang memiliki keinginan rasional dan berbeda dari unit sosial lain karena adanya tujuan yang ingin dicapai, serta berupaya meningkatkan kepuasan melalui peningkatan konsumsi terhadap barang dan jasa (Nasir, 2015).

Desa Cayur berada di Kecamatan Cikatomas Kabupaten Tasikmalaya yang mayoritas masyarakatnya hidup sebagai petani. Usahatani utama yang dilakukan petani di Desa Cayur yaitu usahatani padi sawah. Desa Cayur memiliki luas lahan dan produksi terbesar dari 9 desa yang ada di Kecamaatan Cikatomas dengan luas tanam 387,2 ha, luas panen 387,2 ha, produksi 2.458 ton dengan produktivitas 6,4 ton/ha (BP3K Kecamatan Cikatomas, 2019).

Namun dengan kepemilikan lahan petani responden yang mayoritas sempit sejalan dengan pendapatan petani yang rendah, ditambah lagi petani berusahatani padi sawah secara subsisten. Hal ini menyebabkan rendahnya pendapatan petani padi sawah. Pendapatan petani dari hasil produksi padi sawah yang rendah dan tidak dapat memenuhi semua kebutuhan rumah tangga petani padi sawah di Desa Cayur, menyebabkan sebagian dari anggota rumah tangga mencari alternatif sumber pendapatan dengan meningkatkan alokasi curahan tenaga kerja di luar usahatani padi 
sawah yang pada akhirnya meningkatkan keragaman sumber-sumber pendapatan.

Beragamnya sumber pendapatan akan berpengaruh terhadap stuktur pendapatan rumah tangga petani, serta akan berpengaruh terhadap distribusi pendapatan rumah tangga petani. Stuktur dan distribusi pendapatan akan menggambarkan tingkat kesejahteraan rumah tangga petani padi sawah.

Oleh karena itu penelitian ini bertujuan untuk mengkaji: 1) Struktur pendapatan rumah tangga petani padi sawah di Desa Cayur Kecamatan Cikatomas Kabupaten Taikmalaya; 2) Distribusi pendapatan rumah tangga petani padi sawah di Desa Cayur Kecamatan Cikatomas Kabupaten Taikmalaya; 3) Tingkat kesejahteraan rumah tangga petani padi sawah di Desa Cayur Kecamatan Cikatomas Kabupaten Tasikmalaya.

\section{METODE PENELITIAN}

Penelitian ini dilaksanakan di Desa Cayur Kecamatan Cikatomas Kabupaten Tasikmalaya dengan menggunakan metode survei. Sampel responden ditentukan secara acak menggunakan rumus slovin pada tingkat kesalahan 15 persen dari ukuran populasi sebanyak 219 orang dan didiperoleh jumlah sampel sebanyak 37 orang. Data yang dikumpulkan dalam penelitian ini terdiri atas data primer dan data sekunder.

Tujuan penelitian pertama dianalisis secara deskriptif menggunakan rumus:

$\mathrm{Prt}=\mathrm{P}$ on farm $+\mathrm{P}$ off farm $+\mathrm{P}$ non farm

Keterangan:

Prt $=$ Pendapatan rumah tangga petani/thn $\mathrm{P}$ on farm $=$ Pendapatan dari usahatani

P off farm = Pendapatan dari luar usahatani

$\mathrm{P}$ non farm = Pendapatan dari luar pertanian

Tujuan penelitian kedua dianalisis secara deskriftif menggunakan rumus indek gini: (BPS 2014)

$$
G R=1-\sum_{1}^{k} f_{i}\left(Y_{i-1}+Y_{i}\right)
$$

Keterangan :

$$
\begin{aligned}
& \mathrm{GR}= \text { Gini Ratio }(0<\mathrm{GR}<1) \\
& \mathrm{Fi}= \text { Persentase kumulatif penerimaan } \\
& \text { pendapatan sampai kelompok ke } \mathrm{i}
\end{aligned}
$$

Berikut penilaian tinggi rendahnya ketimpangan distribusi pendapatan, antara lain: (Oshima, 2005)
a. Indeks Gini kurang dari 0,3 menunjukkan ketimpangan distribusi pendapatan yang rendah.
b. Indeks Gini antara 0,3-0,5 menunjukkan ketimpangan distribusi pendapatan sedang.
c. Indeks Gini lebih besar atau sama dengan 0,5 menunjukkan ketimpangan distribusi pendapatan yang tinggi.


Tujuan penelitian ketiga dianalisis secara deskriptif berdasarkan daya beli rumah tangga petani (DBRT), nilai tukar petani (NTP), dan sebelas indikator BPS dalam SUSENAS 2016. Dengan menggunakan rumus:

$$
\mathrm{DBRT}=\mathrm{TP} /(\mathrm{TE}-\mathrm{BU})
$$

\section{Keterangan:}

DBRT $=$ Daya beli rumah tangga petani

$\mathrm{TP}=$ Total pendapatan rumah tangga petani ( $\mathrm{Rp} / \mathrm{th})$ dari seluruh sumber

$\mathrm{TE}=$ Total pengeluaran rumah tangga petani (Rp/th)

$\mathrm{BU}=$ Biaya usahatani

$$
\mathrm{NTPRP}=\mathrm{Y} / \mathrm{E}
$$

Keterangan:

NTPRP = Nilai tukar pendapatan rumah tangga petani

$\mathrm{Y}=$ Total pendapaan rumah tangga

$\mathrm{E}=$ Total pengeluaran rumag tangga

$\mathrm{TK}=\mathrm{I} 1+\mathrm{I} 2+\mathrm{I} 3+\mathrm{I} 4+\mathrm{I} 5+\mathrm{I} 6+\mathrm{I} 7+\mathrm{I} 8+$

$$
\mathrm{I} 9+\mathrm{I} 10+\mathrm{I} 11
$$

Keterangan:

TK $=$ Tingkat kesejahteraan

I1 = Pendapatan rumah tangga

I2 = Konsumsi/pengeluaran rumah tangga

I3 = Keadaan tepat tinggal

I4 = Fasilitas tempat tinggal

I5 = Kesehatan anggota rumah tangga

I6 = Kemudahan mendapatkan pelayanan kesehatan

$\mathrm{I} 7$ = Kemudahan memasukan anak ke jenjang pendidikan
I8 = Kemudahan mendapatkan fasilitas transportasi

I9 = Kehidupan beragama

$\mathrm{I} 10=$ Rasa aman dari tindakan kejahatan

I11 = Kemudahan dalam melakukan olah raga

Tingkat kesejahteraan dibagi menjadi tiga klasifikasi tingkatan, yaitu: tinggi, sedang dan rendah. Penentuan tingkat kesejahteraan dikelompokkan ke dalam tiga bagian:

a) Skor antara 27-35 (Tingkat kesejahteraan tinggi)

b) Skor antara 19-26 (Tingkat kesejahteraan sedang)

c) Skor antara 11-18 (Tingkat kesejahteraan rendah).

\section{HASIL DAN PEMBAHASAN}

Desa Cayur dengan luas wilayah \pm 2.085,5 hekta terdiri dari 8 kedusunan, 13 rukun warga (rw) dan 27 rukun tetangga (rt) dengan jumlah penduduk 7.743 jiwa, terdiri dari laki-laki 3.772 jiwa dan perempuan 3.971 jiwa. Keadaan wilayah Desa Cayur secara umum merupakan desa dengan topography dataran rendah. (Profil Desa Cayur, 2020).

Karakteristik petani yang diteliti dalam penelitian ini meliputi umur, pendidikan, pengalaman, luas lahan, dan tanggungan keluarga (Tabel 1). 
Tabel 1. Karakteristik Petani Padi Sawah di Desa Cayur

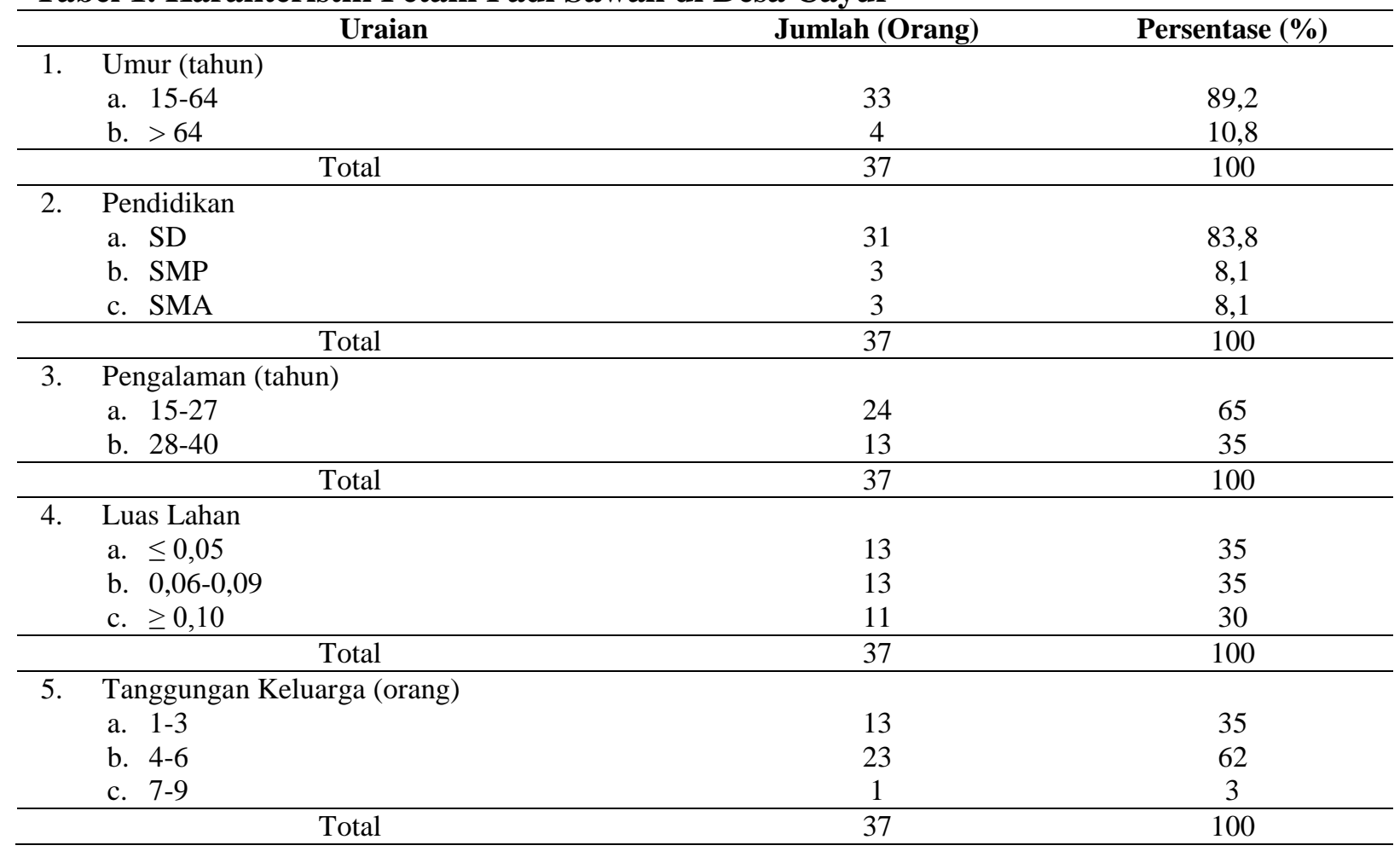

Umur petani bervariasi yang berkisar antara 39-70 tahun dengan rata-rata berumur 52 tahun, sehingga berada pada rentang usia produktif. Banyaknya petani yang berumur produktif menunjukkan bahwa potensi pengembangan usahatani padi sawah masih dinilai prospektif sekalipun selalu dihadapkan pada risiko kegagalan produksi (Badan Pusat Statistik, 2000).

Tingkat pendidikan petani padi sawah pada umumnya masih tergolong rendah, sebagian besar didominasi oleh tamatan Sekolah Dasar (SD). Petani dengan pendidikan formal yang rendah jumlahnya lebih mendominasi, hal ini menyebabkan kemampuan petani dalam mengelola usahatani padi sawah menjadi kurang maksimal yang pada gilirannya akan menurunkan produktivitas petani dalam menghasilkan produk pertanian dan tanaman pangan.

Pengalaman usahatani padi sawah yang dimiliki oleh petani bervariasi, berkisar antara 15-40 tahun dengan rata-rata 27 tahun. Tanggungan keluarga petani bervariasi yang berkisar 2-7 orang dengan rata-rata 4 orang (ukuran keluarga sedang).

Luas lahan yang diusahakan oleh petani bervariasi, berkisar antara 0,03-0,35 hektar dengan rata-rata 0,10 hektar. Umumnya responden mempunyai luas lahan usahatani padi sawah kurang dari 0,5 hektar, artinya responden bertanam padi 
sawah dengan lahan yang tergolong sempit (Suratiyah, 2006).

\section{Struktur Pendapatan Rumah Tangga}

Pendapatan Rumah Tangga petani padi swah di Desa Cayur diperoleh dari berbagai sumber pendapatan baik berasal dari usahatani (on farm), non usahatani (off farm), dan non pertanian (non farm).

Tabel 2. Rata-rata Pendapatan Total Rumah Tangga Petani Padi Sawah di Desa Cayur, Tahun 2020

\begin{tabular}{clcr}
\hline No. & \multicolumn{1}{c}{ Sumber Pendapatan } & $\begin{array}{c}\text { Pendapatan } \\
\text { (Rp/th) }\end{array}$ & $\begin{array}{c}\text { Persentase } \\
(\boldsymbol{\%})\end{array}$ \\
\hline 1. & Usahatani (On Farm) & $5.536 .114,7$ & 19,77 \\
2. & Non Usahatani (Of Farm) & $9.742 .702,70$ & 34,79 \\
3. & Non-Pertanian & $13.039 .459,46$ & 46,56 \\
\hline & Total Pendapatan & $\mathbf{2 8 . 3 1 8 . 2 7 6 , 8 8}$ & $\mathbf{1 0 0}$ \\
\hline
\end{tabular}

Sumber : Data Diolah 2020

Berdasarkan Tabel 2 menunjukan sumber pendapatan rumah tangga petani padi sawah di Desa Cayur, bahwa sumber pendapatan yang paling besar di dapat adalah dari non-pertanian. Hal ini disebabkan karena kegiatan usaha di luar usahatani merupakan salah satu alternatif mata pencaharian rumah tangga, terutama bagi angkatan kerja muda yang relative berpendidikan dan memiliki keterampilan.

Dalam penelitian ini struktur pendapatan rumah tangga petani padi sawah dibagi menjadi dua kelompok yaitu pendapatan sektor pertanian dan non pertanian. Sumber pendapatan di sektor pertanian adalah kontribusi dari pendapatan usahatani padi sawah, usahatani non padi dan nonusahatani. Sedangkan pendapatan nonpertanian terdiri dari kontribusi pendapatan jasa non-pertanian, buruh non-pertanian dan lainnya (Tabel 3).

Tabel 3. Kontribusi Pendapatan Rumah Tangga Petani Menurut Jenis Pendapatan (Rata-rata/tahun)

\begin{tabular}{llrrr}
\hline No. & Sumber Pendapatan & $\begin{array}{c}\text { Pendapatan } \\
(\mathbf{R p} / \mathbf{t h})\end{array}$ & $\begin{array}{c}\text { Sumber } \\
\text { Pendapatan } \\
(\mathbf{\%})\end{array}$ & $\begin{array}{c}\text { Total } \\
\text { Pendapatan } \\
(\mathbf{\%})\end{array}$ \\
\hline 1. & Pertanian & $15.278 .817,42$ & & 54 \\
& Usahatani Padi & $5.231 .493,1$ & 18,5 & \\
& Usahatani Non-Padi & $304.621,62$ & 1,1 & \\
& Off Farm & $9.742 .702,70$ & 34,4 & 46 \\
2. & Non-Pertanian & $13.039 .459,46$ & 46,0 & $\mathbf{1 0 0}$ \\
\hline
\end{tabular}

Sumber : Data Diolah 2020 
Bila dilihat dari sumber pendapatan utama, sektor pertanian merupakan sektor yang memberikan konstribusi pendapatan paling besar yaitu sebesar $54 \%$ terhadap pendapatan rumah tangga petani padi sawah, sedangakn sektor non-pertanian memberikan kostribusi sebesar $46 \%$ terhadap pendapatan rumah tangga petani padi sawah di Desa Cayur.

Hal ini menunjukkan bahwa petani padi sawah di Desa Cayur menggantungkan hidupnya di sektor pertanian. Sedangkan dilihat dari pendapatan non-pertanian petani padi sawah di Desa Cayur sangat rendah.

\section{Distribusi Pendapatan Rumah Tangga}

Distribusi pendapatan digunakan untuk melihat ketimpangan pendapatan antara rumah tangga di Desa Cayur. Untuk mengetahui distribusi pendapatan dilakukakan dengan mengurutkan jumlah total pendapatan rumah tangga perbulan, mulai dari total pendapatan terendah sampai tertinggi. Kemudian membagi kedalam tiga kelompok yang masing-masing $40 \%$ terendah, $40 \%$ sedang, dan $20 \%$ tertinggi (Tabel 4).

Tabel 4. Indeks Gini Rasio Petani Padi Sawah di Desa Cayur

\begin{tabular}{ccrrrr}
\hline $\begin{array}{c}\text { Kelompok } \\
\text { Pendapatan }\end{array}$ & \multicolumn{1}{c}{$\begin{array}{c}\text { Pendapatan } \\
\text { Penduduk }\end{array}$} & $\begin{array}{c}\text { \% Komulatif } \\
\text { Penduduk }\end{array}$ & $\begin{array}{c}\text { Pendapatan } \\
\text { Komulatif }\end{array}$ & $\begin{array}{c}\text { Yi + } \\
\text { Yi - 1 }\end{array}$ & \multicolumn{1}{c}{$\mathbf{f i ( Y i +}$ Yi - 1) } \\
\hline 40\% Terendah & $24.815 .698,61$ & 28,41 & 28,41 & 28,41 & 0,114 \\
40\% Menengah & $37.153 .462,50$ & 42,54 & 70,95 & 99,37 & 0,397 \\
20\% Tertinggi & $25.366 .852,31$ & 29,05 & 100,00 & 199,37 & 0,399 \\
Jumlah & $87.336 .013,43$ & 100 & & & 0,910 \\
\hline \multicolumn{7}{c}{ Gini Rasio } & & & $\mathbf{0 , 0 9}$ \\
\hline
\end{tabular}

Sumber : Data Diolah 2020

Berdasarkan hasil penelitian ini Nilai Indeks Gini Ratio yang diperoleh sebesar 0,09. Angka Rasio Gini tersebut menunjukkan bahwa distribusi pendapatan rumah tangga petani padi sawah di Desa Cayur berada pada tingkat ketimpangan rendah, artinya kemerataan pendapatan petani sudah cukup baik walaupun ada beberapa petani memiliki pendapatan yang lebih besar atau berbeda dengan petani lainnya.

\section{Tingkat Kesejahteraan Rumah Tangga}

a. Tingkat Daya Beli Rumah Tangga

Daya beli rumah tangga petani dapat menunjukkan indikator kesejahteraan ekonomi petani. Semakin tinggi tingkat daya beli petani, maka semakin baik juga akses petani untuk mendapatkan pangan sehingga tingkat ketahanan pangan keluarga manjadi lebih baik (Sudana,2008).

Dapat dilihat pada tabel 5 bahwa daya beli petani padi sawah $>1$ artinya 
pendapatan petani lebih besar dari pengeluaran yang dikeluarkan petani. Ratarata daya beli rumah tangga petani padi di Desa Cayur yaitu sebesar 1,06. Berdasarkan hal tersebut pendapatan petani berbanding besar dengan daya beli rumah tangga petani. Semakin besar pendapatan yang diterima petani maka semakin besar daya beli rumah tangga petaninya.

Tabel 5. Tingkat Daya Beli Rumah Tangga Petani Padi Sawah di Desa Cayur

\begin{tabular}{cc}
\hline DBRTP & $\begin{array}{c}\text { DBRT } \\
\text { Padi Sawah }\end{array}$ \\
\hline Min & 1,01 \\
Max & 1,17 \\
\hline Rata-rata & $\mathbf{1 , 0 6}$ \\
\hline
\end{tabular}

Sumber : Data Diolah 2020

b. Nilai Tukar Pendapatan Rumah Tangga

Tingkat kesejahteraan rumah tangga petani dapat didekati dengan konsep Nilai Tukar Petani (NTP) yang merupakan rasio indeks harga yang diterima dan indek harga yang dibayar petani (Alfrida, 2018).

Semakin besar nilai NTPRP tingkat kesejakteraan petani semakin tinggi. Nilai NTPRP <1 menunjukkan bahwa total pengeluaran rumah tangga petani lebih besar dibandingkan dengan total pendapatan rumah tangga petani. Artinya, petani belum mampu memenuhi kebutuhan untuk usaha pertanian dan non pertanian. Dilihat dari Tabel 6, bahwa presentase untuk NTPRP < 1 yaitu 0 dari total responden lahan padi sawah dan nilai ratarata NTPRP $>1$.

Tabel 6. Nilai Tukar Pendapatan Rumah Tangga Petani (NTPRP) Terhadap Pengeluaran Total

\begin{tabular}{cc}
\hline NTPRT & $\begin{array}{c}\text { NTPRT } \\
\text { Responden }\end{array}$ \\
\hline Min & 0,97 \\
Max & 1,14 \\
Rata-rata & 1,04 \\
Presentase NTPRP $<1$ & 0,00 \\
\hline
\end{tabular}

Sumber : Data Diolah 2020

c. Indikator Kesejahteraan Menurut BPS

Berdasarkan hasil rekapitulasi dari indikator-indikator tingkat kesejahteraan menurut BPS dalam SUSENAS (2016), mengindikasikan petani padi sawah di Desa Cayur memiliki keadaan ekonomi, kesehatan, tempat tinggal, dan fasilitasfasilitas penunjang untuk memenuhi kebutuhan sehari-hari yang layak.

Tingkat kesejahteraan rumah tangga petani padi sawah di Desa Cayur, Kecamatan Cikatomas, Kabupaten 
Tasikmalaya termasuk kesejahteraan tinggi.

Skor tertinggi adalah 30 dan skor terendah adalal 27. Apabila dengan perhitungan bobot maka skor tertinggi adalah 3,0 dan sekor terendah adalah 2,6 dengan rata-rata skor 27,9. Skor tersebut memiliki rentang yang masih termasuk dalam kategori tingkat kesejahteraan tinggi. Faktor yang paling mempengaruhi adalah faktor pendapatan dan faktor pengeluaran.

Tabel 11. Rekapitulasi Tingkat Kesejahteraan Petani Padi Sawah

\begin{tabular}{ccccc}
\hline Kriteria & Skor & Skor Bobot & Jumlah & Persentase (\%) \\
\hline Kesejahteraan Tinggi & $27-35$ & $2,6-3,4$ & 37 & 100 \\
KesejahteraanSedang & $19-26$ & $1,7-2,5$ & 0 & 0 \\
Kesejahteraan Rendah & $11-18$ & $0,8-1,6$ & 0 & 0 \\
\hline
\end{tabular}

Sumber : Data Diolah 2020

\section{KESIMPULAN DAN SARAN}

\section{Kesimpulan}

Berdasarkan hasil penelitian yang telah dilakukan di Desa Cayur, maka diperoleh kesimpulan yaitu:

1. Struktur pendapatan rumah tangga petani padi sawah di Desa Cayur berasal dari usahatani (on farm), non-usahatani (off farm), dan non-pertanian (non farm). Sektor pertanian merupakan sektor yang memberikan konstribusi pendapatan paling besar yaitu sebesar $54 \%$ terhadap pendapatan rumah tangga petani.

2. Distribusi pendapatan menunjukkan ketimpangan rendah dengan gini ratio sebesar 0,09 artinya tidak terjadi ketimpangan pendapatan pada petani padi sawah di Desa Cayur, Kecamatan Cikatomas, Kabupaten Tasikmalaya.
3. Analisis Tingkat kesejahteraan rumah tangga petani padi sawah di Desa Cayur seluruhnya dikategorikan tidak miskin. Berdasarkan 11 indikator ekonomi dan sosial (BPS-SUSENAS 2016) sekor rata-rata yang di peroleh adalah 27,9 yang menunjukkan tingkat kesejahteraan seluruh rumah tangga petani termasuk tingkat sejahtera tinggi.

\section{Saran}

Petani harus meningkatkan keterampilan yang dimiliki atau diperlukan adanya penciptaan lapangan pekerjaan di sektor pertanian dengan cara menumbuhkan agroindustri untuk meningkatkan pendapatan rumah tangga petani sehingga dapat menciptakan kesejahteraan.

\section{DAFTAR PUSTAKA}

Alfrida, A. Noor, T, I. 2018. Analisis Pendapatan dan Tingkat Kesejahteraan Rumah Tangga Petani Padi Sawah Berdasarkan Luas Lahan. 
Jurnal Ilmiah Mahasiswa Agroinfo Galuh. 4 (3):803-810.

Badan Pusat Statistik. 2014. Jakarta. BPS.

Balai Penyuluhan Pertanian, Perikanan dan Kehutanan Kecamatan Cikatomas. 2019. Luas Areal dan Produksi Tanaman Pangan. BP3K.

Martina. Riyandhi, P. 2018. Analisis Tingkat Kesejahteraan Petani Padi Sawah di Kabupaten Aceh Utara. Agrifo. 3(2):27-34.

Nasir, dkk. 2015. Analisis Struktur dan Distribusi Pendapatan Rumah Tangga Petani di Lahan Rawa Lebak. AGRISEP.14(1):97-107.

Oshima, H.T. 2005. Ketimpangan Pendapatan dan Pertumbuhan Ekonomi. Pengalaman Masa Sesudah Perang di Negara-negara Asia, dalam Teori Ekonomi dan Penerapannya di Asia: Ekonomi Pembangunan dan Ekonomi
Pertanian. Jakarta: PT. Gramedia Pustaka Utama.

Rachman, H.P. 2013. Struktur dan Distribusi Pendapatan Rumah Tangga Petani Lahan Sawah diluar Pulau Jawa. Tesis. Universitas Gajah Mada. Yogyakarta.

Suratiyah, K. 2006. Ilmu usahatani. Penebar Swadaya. Jakarta

Sugiyono. 2017. Metode Penelitian Kuantitatif, Kualitatif dan $R \& D$. Bandung: Alfabeta, CV.

Survei Sosial Ekonomi Nasional (SUSENAS). 2016.

Yusuf, M.N. Lies. S. Tuhpawana, P.S. Nono. C. 2017. Struktur Pendapatan dan Pengeluaran Rumah Tangga Petani Padi Sawah di Daerah Rawan Banjir Kabupaten Pangandaran. Universitas Galuh Ciamis dan Universitas Padjadjaran Bandung. 